\title{
LA-UR-12-21423
}

Approved for public release; distribution is unlimited.

Title:

Radioactive Liquid Waste Treatment Facility Discharges in 2011

Author(s): $\quad$ Del Signore, John C.

Intended for: $\quad$ Report

Disclaimer:

Los Alamos National Laboratory, an affirmative action/equal opportunity employer,is operated by the Los Alamos National

Security, LLC for the National NuclearSecurity Administration of the U.S. Department of Energy under contract DE-AC52-06NA25396. By approving this article, the publisher recognizes that the U.S. Government retains nonexclusive, royalty-free license to publish or reproduce the published form of this contribution, or to allow others to do so, for U.S. Government purposes.

Los Alamos National Laboratory requests that the publisher identify this article as work performed under the auspices of the

U.S. Departmentof Energy. Los Alamos National Laboratory strongly supports academic freedom and a researcher's right to publish; as an institution, however, the Laboratory does not endorse the viewpoint of a publication or guarantee its technical correctness. 


\section{Radioactive Liquid Waste Treatment Facility}

\section{Discharges in 2011}

J.C. Del Signore

March 2012 


\section{Table of Contents}

1. Purpose

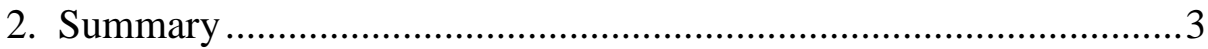

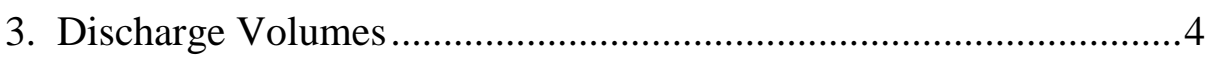

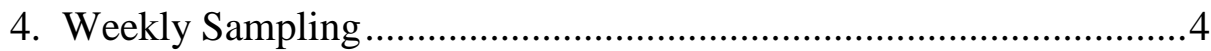

5. Monthly Composite Sampling and Results .......................................5

6. Radioactive Quantities ....................................................................

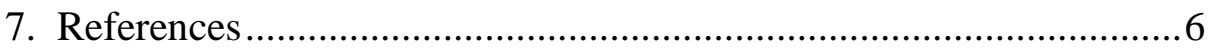

Appendix: Regulatory Change in 2010...............................................

\section{Acronyms and Abbreviations}

$\mathrm{Ci} \quad$ curie $\left(3.7 \times 10^{10}\right.$ disintegrations per second $)$

DL detection limit

DOE United States Department of Energy

EPA United States Environmental Protection Agency

IX ion exchange

L liter

LANL Los Alamos National Laboratory

$\mathrm{nCi} / \mathrm{L} \quad$ nanocuries per liter $\left(10^{-9}\right.$ curies per liter $)$

NMED New Mexico Environment Department

NPDES National Pollutant Discharge Elimination System

$\mathrm{pCi} / \mathrm{L} \quad$ picocuries per liter $\left(10^{-12}\right.$ curies per liter $)$

RLW radioactive liquid waste(s)

RLWTF radioactive liquid waste treatment facility

TA technical area 


\section{Radioactive Liquid Waste Treatment Facility Discharges in 2011}

\section{Purpose}

This report documents radioactive discharges from the TA50 Radioactive Liquid Waste Treatment Facilities (RLWTF) during calendar 2011.

\section{Summary}

During 2011, three pathways were available for the discharge of treated water to the environment: discharge as water through NPDES Outfall 051 into Mortandad Canyon, evaporation via the TA50 cooling towers, and evaporation using the newly-installed natural-gas effluent evaporator at TA50. Only one of these pathways was used; all treated water $(3,352,890$ liters) was fed to the effluent evaporator.

The quality of treated water was established by collecting a weekly grab sample of water being fed to the effluent evaporator. Forty weekly samples were collected; each was analyzed for gross alpha, gross beta, and tritium.

Weekly samples were also composited at the end of each month. These flow-weighted composite samples were then analyzed for 37 radioisotopes: nine alpha-emitting isotopes, 27 beta emitters, and tritium. These monthly analyses were used to estimate the radioactive content of treated water fed to the effluent evaporator. Table 1 summarizes this information.

Table 1

RLWTF Discharges of Treated Water During 2011

\begin{tabular}{|lccc|}
\hline & $\begin{array}{c}\text { Avg.Conc. } \\
(\mathrm{Ci} / \mathrm{L})\end{array}$ & $\begin{array}{c}\text { Flow } \\
(\mathrm{L})\end{array}$ & $\begin{array}{c}\text { Evap.Feed } \\
\text { (Curies) }\end{array}$ \\
\hline & & & \\
Alpha & $2.94 \mathrm{E}-11$ & $3.35 \mathrm{E}+06$ & $9.9 \mathrm{E}-05$ \\
Beta & $4.79 \mathrm{E}-11$ & $3.35 \mathrm{E}+06$ & $1.6 \mathrm{E}-04$ \\
Tritium & $1.09 \mathrm{E}-08$ & $3.35 \mathrm{E}+06$ & $3.7 \mathrm{E}-02$ \\
\hline
\end{tabular}

The concentrations and quantities of radioactivity in Table 1 are for treated water fed to the evaporator. Amounts of radioactivity discharged to the environment through the evaporator stack were likely smaller since only entrained materials would exit via the evaporator stack. 


\section{Discharge Volumes}

A new treatment step, the effluent evaporator, was added to the RLWTF in 2011. This addition created another pathway for discharging treated water, or effluent, to the environment. Design of the effluent evaporator started in September 2010; installation and testing were completed just before the Christmas holidays of that year, and the unit started operation at the TA50 RLWTF on 01-03-2011.

The effluent evaporator was operated on 188 days during calendar 2011. A total of 3.35 million liters of treated water were discharged to the environment as steam from the evaporator stack. Table 2 provides a monthly summary.

Table 2

Discharges of Treated Water to the Effluent Evaporator During 2011

\begin{tabular}{|c|c|c|c|}
\hline \multirow[t]{2}{*}{ Month } & \multicolumn{2}{|c|}{ Production } & \multirow{2}{*}{$\begin{array}{c}\text { Liters } \\
\text { Evaporated }\end{array}$} \\
\hline & Days & Hrs & \\
\hline Jan-11 & 17 & 279 & 291,349 \\
\hline Feb-11 & 13 & 213 & 203,881 \\
\hline Mar-11 & 16 & 268 & 325,645 \\
\hline Apr-11 & 16 & 283 & 244,619 \\
\hline May-11 & 13 & 237 & 244,367 \\
\hline Jun-11 & 13 & 230 & 159,695 \\
\hline Jul-11 & 16 & 297 & 338,197 \\
\hline Aug-11 & 22 & 435 & 386,115 \\
\hline Sep-11 & 17 & 323 & 354,721 \\
\hline Oct-11 & 25 & 475 & 495,329 \\
\hline Nov-11 & 15 & 249 & 234,682 \\
\hline \multirow[t]{2}{*}{ Dec-11 } & 5 & 81 & 74,291 \\
\hline & 188 & 3,369 & $3,352,891$ \\
\hline
\end{tabular}

\section{Weekly Sampling}

In order to characterize the quality of treated water being fed to the evaporator, routine sampling was implemented in February 2011. A grab sample of feed to the effluent evaporator was collected once per week. The first sample was collected Feb-08, and a total of 40 samples were collected during 2011. (The evaporator was not operated during Christmas week, was down for maintenance two other weeks, and did not operate another four weeks due to lack of feed.) These weekly samples are analyzed for gross alpha, gross beta, and tritium in order to provide confidence that treated water being fed to the effluent evaporator was of high quality. 


\section{Monthly Composite Samples and Results}

Samples of evaporator feed from a given month were held, then composited at the end of the month ${ }^{1}$. Monthly composite samples were analyzed for 37 individual radionuclides: nine alphaemitting isotopes, 27 beta-emitters, and tritium. Tables 3 and 4 summarize information by isotope for alpha-emitters and beta-emitters, respectively for 2011.

Alpha results: Seven of the nine alpha-emitters were detected in at least one monthly composite sample; Np-237 and Ra-226 were not detected in any of the eleven monthly composite samples. When added together, a flow-weighted average of $29 \mathrm{pCi} / \mathrm{L}$ resulted for these nine isotopes. U-234 accounted for approximately $60 \%$ of this total; americium and plutonium isotopes accounted for almost all of the remaining alpha radioactivity.

Beta results: Sixteen of the 27 beta emitters were not detected in any of the monthly composite samples. When added together, a flow-weighted average of $48 \mathrm{pCi} / \mathrm{L}$ resulted for the eleven isotopes that were detected in evaporator feed. Eu-152 accounted for approximately one-third of this total.

Tritium results:

$$
\operatorname{Avg}=1.09 \mathrm{E} \mathrm{nCi} / \mathrm{L} \quad \operatorname{Min}=4.9 \mathrm{nCi} / \mathrm{L} \quad \operatorname{Max}=15 \mathrm{nCi} / \mathrm{L}
$$

EPA drinking water standards (40 CFR Parts 141 and 143) are $15 \mathrm{pCi} / \mathrm{L}$ for alpha-emitting radionuclides, and $20 \mathrm{nCi} / \mathrm{L}$ for tritium ${ }^{2}$. A comparison of composite sample analytical results shows that waters fed to the effluent evaporator met the EPA drinking water standard for tritium, and likely met the drinking water standard for beta-emitting radionuclides.

\section{Radioactive Quantities}

Curies of radioactive materials fed to the effluent evaporator during 2011 were calculated by multiplying the feed volume $(3,352,890$ liters) times the flow-weighted average concentration of each radionuclide. As summarized in Tables 3 and 4, feed to the effluent evaporator in 2011 contained approximately $9.9 \mathrm{E}-05$ curie alpha radioactivity and $1.6 \mathrm{E}-04$ curie beta radioactivity. The same calculation, volume times flow-weighted average concentration, yields a quantity of 3.7E-02 curie of tritium in feed to the evaporator.

It should be noted that the concentrations and quantities of radioactivity in Tables 3 and 4 represent effluent fed to the evaporator. The amounts of radioactivity discharged to the environment through the evaporator stack were likely smaller since only entrained materials would exit via the evaporator stack. To quantify the delta between evaporator feed and evaporator discharges to the environment would require sampling of water drained from the evaporator. Drain water was not sampled during 2011, however.

\footnotetext{
${ }^{1}$ Composites are flow-weighted so that results accurately represent water fed to the evaporator.

${ }^{2}$ The drinking water standard for beta-emitting radionuclides is 4 mrem per year.
} 
Table 4

Alpha-Emitting Isotopes

in Feed to the Effluent Evaporator During 2011

\begin{tabular}{|c|c|c|c|c|}
\hline & $\begin{array}{c}\text { Avg } \\
(p C i / L)\end{array}$ & $\begin{array}{c}\operatorname{Max} \\
(\mathrm{pCi} / \mathrm{L})\end{array}$ & $\begin{array}{c}\text { Min } \\
(\mathrm{pCi} / \mathrm{L})\end{array}$ & $\begin{array}{c}\text { Discharge } \\
(\mathrm{Ci})\end{array}$ \\
\hline Am-241 & $4.57 \mathrm{E}+00$ & $1.2 \mathrm{E}+01$ & * & $1.5 \mathrm{E}-05$ \\
\hline $\mathrm{Np}-237$ & * & * & * & * \\
\hline Pu-238 & $4.15 \mathrm{E}+00$ & $1.4 \mathrm{E}+01$ & * & $1.4 \mathrm{E}-05$ \\
\hline Pu-239 & $2.79 \mathrm{E}+00$ & $8.2 \mathrm{E}+00$ & * & $9.4 \mathrm{E}-06$ \\
\hline $\mathrm{Ra}-226$ & * & * & * & * \\
\hline Th-232 & 1.53E-03 & 8.3E-03 & * & 5.1E-09 \\
\hline U-234 & $1.73 \mathrm{E}+01$ & $4.3 \mathrm{E}+01$ & $3.9 \mathrm{E}+00$ & 5.8E-05 \\
\hline U-235 & 3.56E-02 & 7.4E-02 & 7.3E-03 & $1.2 \mathrm{E}-07$ \\
\hline U-238 & $5.85 E-01$ & $1.4 \mathrm{E}+00$ & 3.3E-02 & 2.0E-06 \\
\hline SUM & $2.94 \mathrm{E}+01$ & -- & -- & 9.9E-05 \\
\hline
\end{tabular}

* Less than Detection Limit

Table 5

Beta-Emitting Isotopes

in Feed to the Effluent Evaporator During 2011

\begin{tabular}{|c|c|c|c|c|}
\hline & $\begin{array}{c}\text { Avg } \\
(\mathrm{pCi} / \mathrm{L})\end{array}$ & $\begin{array}{c}\text { Max } \\
(\mathrm{pCi} / \mathrm{L})\end{array}$ & $\begin{array}{c}\operatorname{Min} \\
(\mathrm{pCi} / \mathrm{L}) \\
\end{array}$ & $\begin{array}{c}\text { Discharge } \\
(\mathrm{Ci})\end{array}$ \\
\hline As-74 & $9.21 \mathrm{E}+00$ & $5.3 E+01$ & * & $3.1 \mathrm{E}-05$ \\
\hline Co-58 & 3.63E-01 & $1.5 \mathrm{E}+01$ & * & 1.2E-06 \\
\hline Co-60 & 3.16E-01 & 1.3E+01 & * & 1.1E-06 \\
\hline Cs-137 & $6.37 \mathrm{E}+00$ & $2.8 \mathrm{E}+01$ & * & 2.1E-05 \\
\hline Eu-152 & $1.59 \mathrm{E}+01$ & 1.1E+02 & * & 5.3E-05 \\
\hline $\mathrm{I}-133$ & $3.07 \mathrm{E}+00$ & $1.9 \mathrm{E}+01$ & * & 1.0E-05 \\
\hline $\mathrm{Rb}-83$ & $2.46 \mathrm{E}+00$ & $3.7 \mathrm{E}+01$ & * & 8.3E-06 \\
\hline $\mathrm{Rb}-84$ & $2.91 \mathrm{E}+00$ & $3.8 \mathrm{E}+01$ & * & $9.8 \mathrm{E}-06$ \\
\hline Sr-85 & $2.75 \mathrm{E}+00$ & 1.7E+01 & * & $9.2 E-06$ \\
\hline$V-48$ & 3.89E-01 & 1.6E+01 & * & 1.3E-06 \\
\hline Y-88 & $4.12 \mathrm{E}+00$ & $2.5 \mathrm{E}+01$ & * & 1.4E-05 \\
\hline SUM & $4.79 \mathrm{E}+01$ & -- & -- & 1.6E-04 \\
\hline
\end{tabular}

* Less than Detection Limit 


\section{References}

Clark, R.L., 08-18-2010. "Use of TA-50 Cooling Towers for Treated Effluent From RLWTF". NPR-4344.

Clark, R.L., 08-30-2010. "Natural Gas-Fired Evaporator for Treated Effluent From RLWTF". NPR-4347.

Clark, R.L., 09-21-2010. "Natural Gas-Fired Evaporator for Treated Effluent From RLWTF". NPR-4357.

Department of Energy, 01-17-1993. "Radiation Protection of the Public and the Environment", Order 5400.5, Change 1, Washington, DC.

Environmental Protection Agency, 01-30-1991. "National Secondary Drinking Water Regulations". 40CFR Part 143.

Environmental Protection Agency, 01-22-2001. "National Primary Drinking Water Regulations: Maximum Contaminant Levels and Maximum Residual Disinfectant Levels". 40CFR Part 141, Subpart G.

Environmental Protection Agency, 12-15-1989. "National Emission Standards for Emissions of Radionuclides Other Than Radon From Department of energy Facilities". 40CFR Part 61, Subpart H.

Environmental Protection Agency, 06-08-2007. "Authorization to Discharge Under the National Pollution Discharge Elimination System”, NPDES Permit No. NM0028355, Dallas, TX.

New Mexico Environment Department, 09-20-2010. “No Permit Required”. File No. 2195-U. 


\section{Appendix \\ Regulatory Change in 2010}

\section{Change}

The RLWTF is authorized by the U.S. Environmental Protection Agency and the U.S. Department of Energy to discharge treated water to the environment through an outfall in Mortandad Canyon. The New Mexico Environment Department also monitors the quality of these treated waters.

Effective 08-01-2010, the EPA greatly reduced discharge standards for copper and zinc. The standard for zinc was reduced by a factor of approximately 2,000 to 2.2 micrograms per liter $(\mu \mathrm{g} / \mathrm{L})$; that for copper was reduced by a factor of approximately 10,000 to 0.14 micrograms per liter. As shown in the below table, the EPA had set the former discharge standards approximately equal to drinking water standards, but reduced both to new discharge standards that are more than 2,000 times lower than the EPA drinking water standard.

\section{Standards for Copper and Zinc}

\begin{tabular}{|r|c|c|c|}
\hline & $\begin{array}{c}\text { Drinking } \\
\text { Water Std. }\end{array}$ & $\begin{array}{c}\text { Former } \\
\text { Discharge Std. }\end{array}$ & $\begin{array}{c}\text { New } \\
\text { Discharge Std. }\end{array}$ \\
\hline Copper & $1,300 \mu \mathrm{g} / \mathrm{L}$ & $1,393 \mu \mathrm{g} / \mathrm{L}$ & $0.14 \mu \mathrm{g} / \mathrm{L}$ \\
Zinc & $5,000 \mu \mathrm{g} / \mathrm{L}$ & $4,370 \mu \mathrm{g} / \mathrm{L}$ & $2.2 \mu \mathrm{g} / \mathrm{L}$ \\
\hline
\end{tabular}

Drinking water standards are published at 40 CFR, Parts 141 and 143.

\section{Discharge Pathways}

The RLWTF pilot-tested and installed a novel ion exchange process in an effort to meet these extremely low discharge standards for copper and zinc. The process proved capable of sometimes yielding water that met the standards. Other limitations included were encountered, such as copper and zinc contamination of existing tanks and piping, the fact that laboratory reagents contain copper and zinc in concentrations above the standards, and difficulty in obtaining ion exchange media.

Because treatment processes to consistently achieve the new discharge standards are not commercially available, LANL was faced with either developing alternative discharge pathways for treated water, or curtailing defense-related missions. Four additional alternative pathways were developed:

- trucking water to the TA53 solar evaporation tanks; 
- evaporation by feeding treated water to cooling towers located at the RLWTF;

- evaporation by using a natural-gas evaporator; and

- construction of solar evaporation tanks dedicated for use by the RLWTF.

In addition to discharges to Mortandad Canyon, two of the four alternative pathways were used during calendar 2010: trucking water to TA53 and evaporation via the cooling towers. The second half of 2010 was also used for the design and installation of a natural-gas evaporator, and to continue the design of solar evaporation tanks.

During 2011, three discharge pathways were available: discharges through the NPDES outfall to Mortandad Canyon, feeding to the TA50 cooling towers for evaporation, and feeding to a natural-gas effluent evaporator ${ }^{3}$. Only one of these pathways was used; all treated water was discharged to the effluent evaporator.

\section{Effluent Evaporator}

A new treatment step, the effluent evaporator, started operation at the RLWTF on 01-03-2011. This addition created another pathway for discharging treated water, or effluent, to the environment. Design of the effluent evaporator started in September 2010; installation and testing were completed just before the Christmas holidays of that year.

The effluent evaporator is constructed of 316 stainless steel, and has approximate dimensions of $17^{\prime} \times 9^{\prime} \times 10^{\prime}$ ( $\left.\mathrm{L} \times \mathrm{W} \times \mathrm{H}\right)$. The evaporator is equipped with two natural-gas burners with lowNOx controls, a 6000-CFM blower, a heat exchanger, and a stack mist eliminator. It has a capacity of 4.5 million BTU per hour. The evaporator and its components are protected within a weather-resistant housing identified as Building 50-250, which is located about 20 feet east of Room 34B of Building 50-01.

From the treated water storage tanks in Room 34B, water is pumped into a reservoir (capacity of $\sim 1700$ gallons) at the evaporator. Water in the reservoir is heated to boiling, and leaves via the stack as a vapor. Evaporation lowers the water level in the reservoir, and triggers a call for more water to be automatically fed to the reservoir. Either or both burners can be used to heat the water.

\footnotetext{
${ }^{3}$ The State of New Mexico directed that treated water not be trucked from TA50 to TA53, beginning in 2011.
} 